\title{
The Effect of a Budget Deficit on Inflation: The Case of Tanzania
}

\section{Solomon and W A de Wet}

Department of Economics, University of Pretoria

\section{ABSTRACT}

The Tanzanian economy has remained one of the limited numbers of countries that has experienced a relatively high inflation rate, accompanied by high fiscal deficits for a prolonged period in the absence of any hyperinflation. This paper examines the deficit-inflation relationship in the Tanzanian economy and establishes the causal link that runs from the budget deficit to the inflation rate using cointegration analysis over the period 1967-2001. Some dynamic simulations are done to gauge the effect of a change in the budget deficit and gross domestic product on inflation over time. Due to monetisation of the budget deficit, significant inflationary effects are found for increases in the budget deficit.

JEL E62, H62

\section{INTRODUCTION}

The fear that the public sector deficit will eventually be monetised and thus lead to inflation is a deep rooted one among economic agents (Buiter, 1985: 21). Often, the recurring question is whether larger public deficits are always associated with higher inflation. Sargent and Wallace (1981) answered the question affirmatively, but their relationship is blurred, because governments finance deficits by borrowing domestic and abroad as well as printing money. Various factors, including unstable demand for money, exchange rate depreciation, and widespread indexation shadow the relationship between money financing of deficits and inflation over shorter periods (Easterly \& Schimdt-Hebbel, 1993: 220).

The Tanzanian economy has remained one of the limited cases that have experienced a relatively high inflation rate, accompanied by high fiscal deficits (for a prolonged period) in the absence of any hyperinflation. This paper examines the deficit-inflation relationship in the Tanzanian economy and establishes the causal link that runs from the budget deficit to the inflation rate using cointegration analysis over the period 1967-2001. Some dynamic 
simulations are done to gauge the effect of a change in the budget deficit and gross domestic product on inflation over time. The budget deficit is found to be significantly inflationary due to the structure of the Tanzanian economy.

The paper is organised as follows. Section 2 gives an overview of the Tanzanian situation, while section 3 discusses the budget deficit and inflation from the monetarist perspective. Section 4 estimates the relationship empirically, while section 5 provides some concluding comments.

\section{THE TANZANIAN ECONOMY, THE BUDGET AND INFLATION}

\subsection{The budget deficit and its financing}

Government deficit spending in Tanzania has been the subject of much concern in Tanzania's current economic problems. Particularly, government spending is considered to have contributed significantly to the country's inflation and external imbalance. Accordingly, surmounting these phenomena has been seen as being very much dependent on securing a closer look at the dynamics of the components of the budget balance.

According to the central bank (Bank of Tanzania) the government has been continuously pursuing an expansionary fiscal policy with the exception of the years 1997,1998 and 2000 . The main culprit for the expansionary fiscal stance was increasing pressure from the public seeking to achieve faster economic growth. The government responded by expanding its expenditure on development projects and infrastructure improvements. However when the impact of the increasing fiscal deficit was felt at the end of 1996, an immediate policy shift was observed. The ensuing macroeconomic instability (high inflation rate and high interest rates) was combated using tight fiscal discipline. The low inflation rate achieved at the end of 1990s and early twenty first century is explained by the introduction of improved fiscal discipline.

The government, with the assistance of the donor community, embarked in 1985 on an ambitious stabilisation and reform agenda. In the fiscal area, efforts were focused on strengthening fiscal management via broad-based policy and administration reforms. At the same time, increased transparency and coordination with donors on macroeconomic policies and structural reforms helped mobilise financial support and kept the share of budget deficit to GDP below 5 per cent.

Looking at how the budget deficit is financed in Tanzania gives a realistic picture of the inflationary effect of the fiscal deficit. In Tanzania, budget deficits 
have been financed from domestic and foreign sources. The source of finance implies a different effect of a budget deficit on inflation. Domestic financing is more inflationary than foreign financing in many developing country economies because of the fact that the economies of these developing countries is characterised by inefficient capital markets and high dependence on developed countries for foreign reserves. Therefore, domestic financing is mostly done by borrowing from the banking system which is often monetised by the government. Tanzania's economy is not different from many other developing countries.

Table 1 Source of total government finance in Tanzania

\begin{tabular}{|l|c|c|c|c|c|}
\hline Years & $\begin{array}{c}\text { Total } \\
\text { financing } \\
\text { (Schilling) }\end{array}$ & $\begin{array}{c}\text { Per cent of } \\
\text { foreign } \\
\text { finance }\end{array}$ & $\begin{array}{c}\text { Per cent of } \\
\text { domestic } \\
\text { finance }\end{array}$ & $\begin{array}{c}\text { Per cent of } \\
\text { non-bank } \\
\text { borrowing }\end{array}$ & $\begin{array}{c}\text { Per cent of } \\
\text { bank } \\
\text { borrowing }\end{array}$ \\
\hline 1984 & $4,824.40$ & 54.1 & 45.9 & -55.6 & 155.6 \\
\hline 1985 & $7,922.10$ & 30.74 & 69.3 & 34.9 & 65.1 \\
\hline 1986 & $7,910.20$ & 49.2 & 50.8 & 53.4 & 46.6 \\
\hline 1987 & $9,715.50$ & 36.4 & 63.6 & 20.3 & 79.7 \\
\hline 1988 & $18,749.50$ & 75.9 & 24.1 & 63.3 & 36.7 \\
\hline 1989 & $24,727.80$ & 80.0 & 20.0 & 47.7 & 52.3 \\
\hline 1990 & $29,728.60$ & 106.0 & -6.0 & -150.9 & 250.9 \\
\hline 1991 & $48,745.90$ & 75.2 & 24.8 & 30.9 & 69.1 \\
\hline 1992 & $42,461.00$ & 121.9 & -21.9 & -62.2 & 162.2 \\
\hline 1993 & $82,230.40$ & 102.6 & -2.6 & -410.9 & 510.9 \\
\hline 1994 & $73,579.60$ & 40.0 & 60.0 & 13.7 & 86.3 \\
\hline 1995 & $104,515.00$ & 61.2 & 38.8 & 65.5 & 34.5 \\
\hline 1998 & $64,559.00$ & 4.6 & 95.4 & 9.4 & 90.6 \\
\hline 1997 & $21,269.50$ & -164.1 & 264.1 & 111.7 & -11.7 \\
\hline 1998 & $-77,139.30$ & 63.6 & 36.4 & 92.9 & 56.5 \\
\hline 1999 & $68,137.20$ & 94.6 & 5.4 & -643.3 & 743.3 \\
\hline 2000 & $-24,423.60$ & 76.5 & 23.5 & 121.4 & -21.4 \\
\hline 2001 & $113,271.60$ & 93.1 & 6.9 & 2.1 & 97.9 \\
\hline
\end{tabular}

Source: Bank of Tanzania

The deficits were largely financed through borrowing from the banking system. Government borrowing from the banking system as a percentage of GDP was as high as 86.3 per cent in 1994 and 90.8 per cent in 1998. In 1990, as stabilisation and liberalization policies and the related reform agendas began to be implemented, the availability of foreign financing increased. As a result the share of foreign financing of the total financing has increased. This has helped support the government in its resolve not to make use of relatively expensive or 
inflationary domestic financing, while allowing sufficient credit resources for the private sector and a necessary build up of foreign reserves. The rationalisation of expenditure programs and the progressive shift from domestic to foreign financing were at the core of Tanzanian macroeconomic stabilization in the middle of the 1990s, contributing to a sharp reduction in inflation.

\subsection{Inflation performance in Tanzania}

The historical trend of inflation in Tanzania shows inflation has always been a two-digit figure starting in 1966. In the 1970s it has been limited to fluctuate between 10 per cent and 20 per cent. At the end of the 1970s and the beginning of 1980, a radical increase was recorded. Inflation rose to the level of 30 per cent. It stabilised at this level, only dropping to 20 per cent at the end of $1980 \mathrm{~s}$. The government of Tanzania's strategy for reducing inflation has, since 1986, focused on tight monetary policy and increased output production. This focus has been determined by the fact that Tanzania's inflation has been both a monetary and a structural phenomenon (Rutayisire, 1986).

The task of slowing down inflation proved difficult. This difficulty was due to structural problems that hindered efficient production (for example, dependence on the weather) and inflationary financing of persistent fiscal deficits, caused by a combination of high government expenditure and poor domestic revenue collection. Inflation remained high during these periods, although at a slightly lower level than the pre-reform level of 22.3 per cent in 1985 . The significant decline in the inflation rate since 1994 reflects the impact of tight monetary and fiscal policies pursued by the central bank and government. One observes that the growth rate in the money supply declined from 32.5 per cent in 1994 to approximately 7.7 per cent in 1998. The budget deficit expressed as a percentage of GDP also declined from 6.4 per cent in 1994 to 2.9 per cent in 1998. The year to year underlying inflation rate, which is the rate of inflation excluding changes in food prices also decreased significantly from 13.8 per cent to 8.0 per cent in 1998 . The decrease is partly attributed to the decline in prices of most non-food group items such as rents, fuel, electricity and water, and transportation.

\section{THEORETICAL LINKS OF THE BUDGET DEFICIT AND INFLATION}

In the monetarist perspective money supply drives inflation. If monetary policy is accommodative to a budget deficit, money supply continues to rise for a long time. Aggregate demand increases as a result of this deficit financing, causing output to increase above the natural level of output. Growing labour demand 
increase wages, which in turn leads to the shift in aggregate supply in a downward direction. After some time the economy returns to the natural level of output. However, this happens at the expense of permanent higher prices.

According to the monetarist view, budget deficits can lead to inflation, but only to the extent that they are monetised (Hamburger and Zwick (1981)). In the monetarist (and neo-classical) models, changes in the inflation rate closely depend on changes in the money supply. Generally, the budget deficit per se does not cause inflationary pressures, but rather affects the price level through the impact on money aggregates and public expectations, which in turn trigger movements in prices. The money supply link of causality rests on Milton Friedman's famous theory of money, which dictates that inflation is always and everywhere a monetary phenomenon. The theory explains that continuing and persistent growth of prices is necessarily preceded or accompanied by a sustained increase in money supply. The expectations link of causality works through the inter-temporal budget constraint, which implies that a government with a deficit must run, in present value-terms, future budget surpluses (Walsh, 1998: 138-57). One possible way to generate surpluses is to increase the revenues from seignorage, so the public might expect future money growth. The deficit-inflation relationship is also discussed by considering direct effects of inflation on outstanding debts, tax revenues and expenditures. The dynamic interaction between public deficits and inflation could go in one of two directions. Either the effect of inflation to reduce the real value of debts dominates, or inflation worsens the fiscal position of the government due to collection lags, which reduces the government's real revenue (Dornbusch, 1990). This fall in the revenue, in itself, is accepted as a contributing factor in the inflationary process by increasing the money supply to finance these inflation-induced deficits (Tanzi, 1991; Aghevli \& Khan, 1978).

Empirical work on the relationship between deficits and inflation has yielded conflicting results. Although the direction of the causation is generally accepted from deficits to inflation empirical evidence on this unidirectional causation is inconclusive (e.g. Abizadeh \& Yousefi, 1998; Ahking \& Miller, 1985; Barnhart \& Darrat, 1988; Dwyer, 1982; Hamburger \& Zwick, 1981; Hondroyiannis \& Papapetrou, 1997). While some studies provide results to support the idea that inflation is caused by deficits, in many studies there is no significant evidence. On the other hand, Aghevli and Khan (1978), Ahking and Miller (1985), Barnhart and Darrat (1988), Hondroyiannis and Papapetrou (1997) find a bidirectional causation between deficits and inflation. Most of the empirical studies have adopted ad hoc approaches using econometric techniques. The relationship has been generally examined through the relationship between money growth and inflation. The monetarist assumption, which suggests that inflation is mainly a result of an increase in the money supply, is explicitly or 
implicitly held in many studies. Even some studies questioning the relevance of the unidirectional relationship between deficits and inflation presume a direct relationship between money growth and inflation (e.g. De Haan \& Zelhorst, 1990; Hondroyiannis \& Papapetrou, 1997; Hamburger \& Zwick, 1981; McMillin \& Beard, 1982).

The most common empirical method to examine the deficit-inflation relationship has been to employ a single equation model for money growth or inflation, treating deficits as an exogenous variable among others (e.g. Abizadeh \& Yousefi, 1998; Ahking \& Miller, 1985; Hamburger \& Zwick, 1981; McMillin \& Beard, 1982). Conclusions have been based on these estimates, and a positive and statistically significant coefficient on the deficit variable has been taken as evidence to support the hypothesis that deficits 'cause' money growth and/or inflation. In such a single equation approach, a possibility for a reverse causation from inflation to deficits is generally ruled out.

It appears that the "budget deficit-inflation" link in fact exhibits a two-way interaction, i.e. not only does the budget deficit through its impact on money and expectations produces inflationary pressure, but high inflation then also has a feedback effect pushing up the budget deficit. Basically, this process works through significant lags in tax collection. The problem lies in the fact that the time of tax obligations' accrual and the time of actual payment do not coincide with payment usually made at a later date. In view of this, high inflation during such a time lag reduces the real tax burden. We may therefore have the following self-strengthening phenomenon: persistence of the budget deficit props up inflation, which in turn lowers real tax revenues; a fall in the real tax revenues then necessitates further increases in the budget deficit and so on. In economic literature this is usually referred to as the Olivera-Tanzi effect.

As Sachs and Larain (1993) show, the evidence from the developing world in the 1980's supports the conclusion that this self-strengthening process may well destabilise an economy and lead to a very high inflation. Some researchers also argue that budget deficit financing by means of accumulating domestic debt seems to only postpone the inflation tax. If government finances its deficit by printing money now, then in the future the burden of servicing existing stock of government debt will be easier. Interest payments that otherwise add to the next periods' government expenditures will not exert additional pressure on fiscal authority and the deficit will not increase over time. As Sachs and Larrain (1993) put it, "borrowing today might postpone inflation, but at the risk of even higher inflation in the future".

Sargent and Wallace (1981) observe that when the fiscal authority sets the budget independently, the monetary authority can only control the timing of 
inflation. Recently a new direction of theory has emerged, which may also be seen as an extension of the deferred inflation hypothesis. According to the new fiscal theory of the price level (see Komulainen \& Pirttila, 2000 and Carzoneri, Cumby \& Diba, 1998) there can be two regimes for price determination. Under the so-called "monetary dominant" regime, monetary policy determines the price level, and fiscal policy remains reactive. The government balances its intertemporal constraint taking the inflation as given. In the "fiscal dominant" regime, in contrast, the price level is determined by the intertemporal budget constraint. If the future surpluses fall short of financing the deficit, the price level must adjust upwards, reducing the real value of the government debt. Monetary policy is reactive in a "fiscal dominant" regime: money supply reacts to price level changes to bring the money demand equation in balance (Carlston \& Fuerst, 1999).

\section{EMPIRICAL ANALYSIS OF TANZANIA'S INFLATION}

The most common empirical method to examine the deficit-inflation relationship has been to employ a single equation model for money growth or inflation, treating deficits as an exogenous variable among others [e.g. Abizadeh and Yousefi (1998), Ahking and Miller (1985), Hamburger and Zwick (1981), McMillin and Beard (1982)]. In this study a four variable single equation model is employed. Budget deficit, GDP and exchange rate are treated as an exogenous variables and inflation (CPI) as an endogenous variable.

\subsection{The model}

For the estimation of the influence of a budget deficit on inflation, one can start from the long run government budget constraint:

$$
\frac{B_{-1}}{P_{t}}=\sum \frac{1}{r_{j}}\left(\tau_{t+j}-g_{t+j}+\left(M_{t+j}-\frac{\left.M_{t-1-j}\right)}{P_{t+j}}\right)\right.
$$

where

$$
\begin{aligned}
& \mathrm{B}_{\mathrm{t}-1} / \mathrm{P}_{\mathrm{t}}=\text { Government debt } \\
& \mathrm{r}_{\mathrm{j}}=\text { The discount rate } \\
& \tau_{t+j}=\text { Total tax revenue } \\
& \mathrm{g}_{\mathrm{t}+\mathrm{j}}=\text { Total government expenditure } \\
& \mathrm{M}_{\mathrm{t}}=\text { Broad money supply }
\end{aligned}
$$

Considering the particular case where the public debt cannot grow implies that the entire budget deficit is ultimately financed through seignorage. Imposing this restriction on the public debt, one obtains the short run budget constraint: 
$\frac{B_{t-1}(t)}{P_{t}}=\tau_{t}-g_{t}+\left(\frac{M_{t}-M_{t-1}}{P_{t}}\right)$

where $\mathrm{B}(\mathrm{t})$ is the debt with the maturity in period $\mathrm{t}$ that has to be paid and is not rolled-over. This can be rewritten as

$$
\frac{B_{t-1}(t)}{P_{t}}-\tau_{t}+g_{t}=\left(\frac{M_{t}-M_{t-1}}{P_{t}}\right)
$$

The term on the left hand side is the budget deficit formed from the fiscal deficit and repayment of public debt with the maturity in period $t$ and the term on the right hand side is seignorage.

Seignorage revenue (S) can be written as a function of the inflation rate and real money supply:

$$
S=f\left(\Pi_{t}\right) M_{t} / P_{t}
$$

where $f\left(\Pi_{t}\right)$ is a reduced form money demand equation.

Considering that seignorage is increasing with the inflation rate and combining equation 3 and equation 4 one obtain the equation estimated by Catao and Terrones (2001) that explains the inflation rate by the budget deficit and money supply:

$$
\Pi_{t}=\beta d_{t} P_{t} / M_{t}^{s}
$$

where $\beta$ is the inverse linear multiplier

$d_{t}$ is the budget deficit which is $d_{t}=g_{t}-T_{t}-B_{t-1}$

$\mathrm{M} / \mathrm{p}$ is the money supply

If one divides by nominal GDP (Y) one obtains a relation between the size of budget deficit (D) in GDP and the level of inflation:

$\Pi=D_{l} / Y_{t} / M_{t} / Y_{t}$

The long run equation developed in this study includes the ratio of the budget deficit to GDP and the exchange rate as exogenous variables and the consumer price index, as the endogenous variable. 
The influence of the budget deficit on inflation is positive. The higher the budget deficit, the greater will be the rate of inflation. The budget deficit affects inflation only if it is monetised to increase the monetary base of the economy. From Friedman's theory of money inflation is a monetary phenomenon. Accordingly if the budget deficit is monetised it increases the money supply thereby increasing the price level. When the budget deficit is monetised, an extremely high correlation exists between the budget deficit and money supply. The problem of multicollinearity and reducibility precludes one from using both money supply and the budget deficit as explanatory variables in the regression analysis. Therefore, in order to estimate the effect of the budget deficit on inflation, the budget deficit is used as explanatory variable instead of the money supply. The exchange rate has a deterministic effect on the level of prices in underdeveloped economies. It's included as a control variable in this paper that can explain inflation. In countries like Tanzania, an exchange rate depreciation (appreciation) could increase (decrease) the price of imported commodities. Tanzania's markets are heavily based on imported commodities, which imply the depreciation of the exchange rate could be immediately reflected on an increase on the price of the consumer's basket of commodities. The third important explanatory variable is the level of GDP, which is negatively related with the level of inflation. The functional form of the model is:

$\mathrm{CPI}=\mathrm{f}($ bdef, exch, $\mathrm{gdp})$

where: $\quad$ cpi is the consumer price index $(1995=100)$

bdef is the consolidated budget deficit (before grants)

gdp is the level of gross domestic product at constant price

exch is the exchange rate of Tanzania's Shilling against U.S.dollar

Annual data obtained from the World Bank and the Bank of Tanzania for the period between 1967-2001 was used. From the ADF test result all the time series variables are non-stationary and exhibit stochastic trends that can be removed by differencing once or more than once (See Appendix A, Table 2 for the results of the ADF tests). The ADF unit root test results show all four variables under discussion [ $\log (\mathrm{cpi}), \log (\mathrm{bdef}), \log (\mathrm{exch}), \log (\mathrm{gdp})]$ are integrated of the order one at a 5 per cent level of significance.

A vector autoregressive (VAR) model with a lag length of 1 was used to test for the number of cointegrating relationships between the variables in the long run equation (Table 3). In order to test for cointegration between the variables, the Johansen test was employed.

For a VAR (1) the Johansen likelihood ratio test for the number of cointegrating relationships (denoted by r), based on the maximum eigenvalue and the trace of 
the stochastic matrix, suggests one cointegration relationship at a 5 per cent level of significance between the variables in the long run cointegration relationship. These results are presented in Table 4. The long run relationship was estimated with no intercept or trend and the figures normalised on the dependent variable is reported in Table 5.

The residual derived from the long run equation, allows for the specification of the error correction model (ECM), representing the short run dynamic adjustment process. This result is reported in Table 6. In the ECM the coefficient on the residual indicates the speed of adjustment towards the long run equilibrium and its value is between -1 and 0 . Large absolute values of the coefficient on the residual shows equilibrium agents remove a large percentage of disequilibrium in each period i.e. the speed of adjustment is very rapid. Low absolute values are indicative of a slow speed of adjustment towards equilibrium. All variables used were in their first differenced form. Dum87 is a dummy variable that represents the change from a highly controlled economic system to a more liberalised economic system in 1987 under the Economic Recovery program. Diagnostic tests in Table 5 suggest that the equation is statistically well specified, with no violations of the Gaussian assumptions.

The result of the ex post simulation of the consumption price function is presented graphically in Figure 1. The aim of the simulation is to determine the policy implications on inflation in Tanzania, with specific reference to the budget deficit.

To observe the sensitivity of the consumer prices in the model to variations in the parameters of the exogenous variables, shocks are induced to two of the independent variables. The independent variables, i.e. the budget deficit and gross domestic product are shocked systematically and variations in the solutions are evaluated in terms of deviations from the base solution. Sensitivity tests in the form of dynamic simulations will determine whether the resulting multiplier effects are consistent. More importantly, it will establish the duration or "pipeline" effects of a shock to a dependent variable on consumer prices. This will enable policy makers to determine how long it takes consumer prices to converge after an increase in the budget deficit or GDP. The variables are shocked one at a time.

Figure 2 reveals that a 10 per cent increase in the budget deficit from 1980 onwards, results in a sharp and almost immediate increase of 30 per cent in the level of inflation. It takes 5 years for consumer prices to converge again to a long run path. As a priori expected, this higher budget deficit is at the expense of permanent higher consumer prices. 


\section{Figure 1 The overall dynamic fit of $\log (\mathrm{cpi})$}

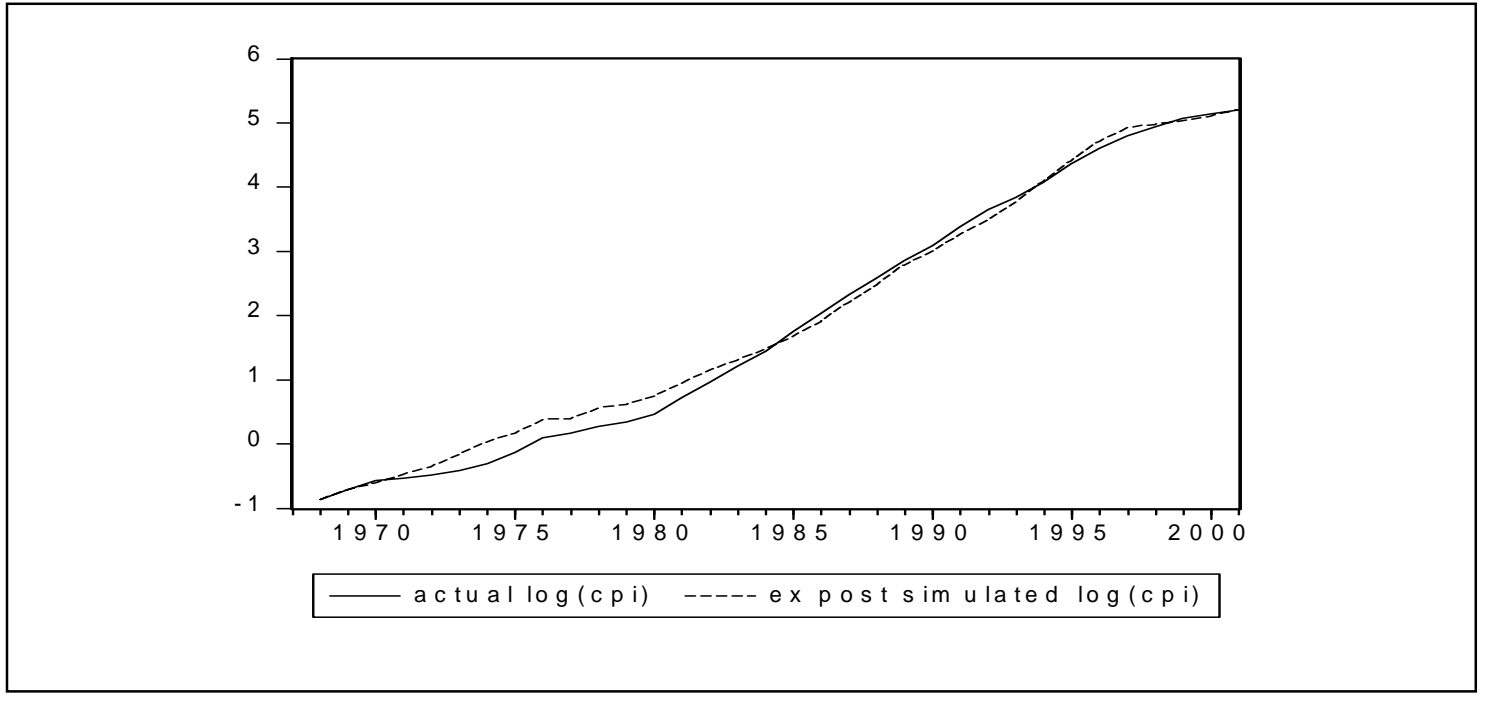

This increase in the budget deficit induce higher inflation due to higher aggregate demand, resulting from an increase in expenditure as well as the increase in money supply, to monetise the increase in the budget deficit.

Figure 2 Dynamic adjustment properties on CPI due to a 10 per cent increase in the budget deficit

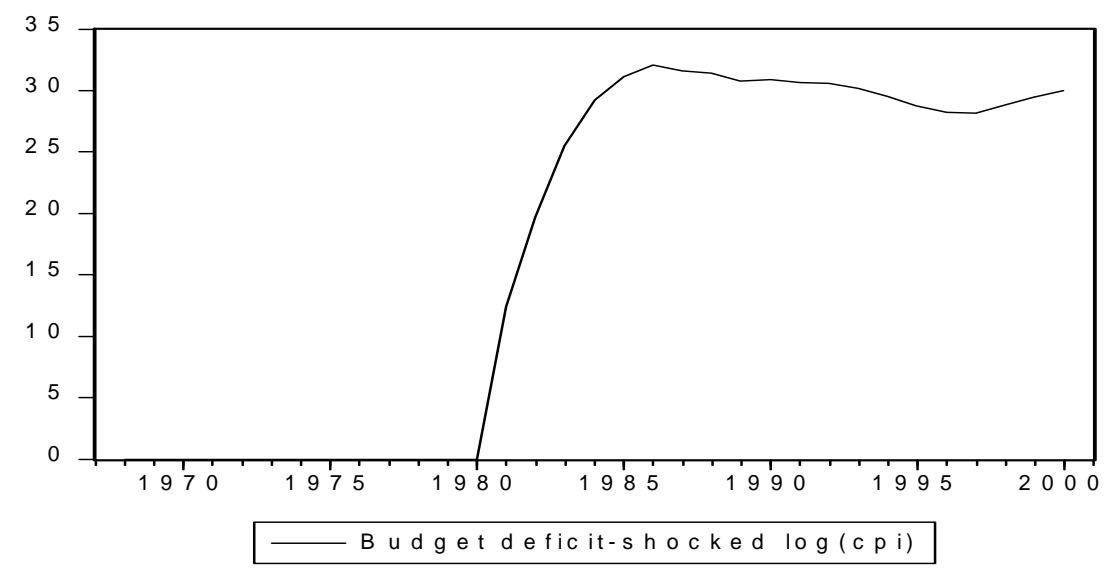

The GDP is increased by 10 per cent permanently from 1980 onwards. The outcome of the shock shown in Figure 3 reveals that consumer prices fall by nearly 35 per cent from its long run equilibrium and converge in 1986 at a lower price level. The increase in output eases the demand pressure in the economy and lowers the level of inflation. The effect is so large because of the structure of the Tanzanian economy. Being an economy that relies heavily on agriculture 
for basic food and income, it often happens that the supply in the economy is insufficient to satisfy demand - especially in dry seasons.

Figure 3 Dynamic adjustment properties on CPI due to a 10 per cent increase in the GDP

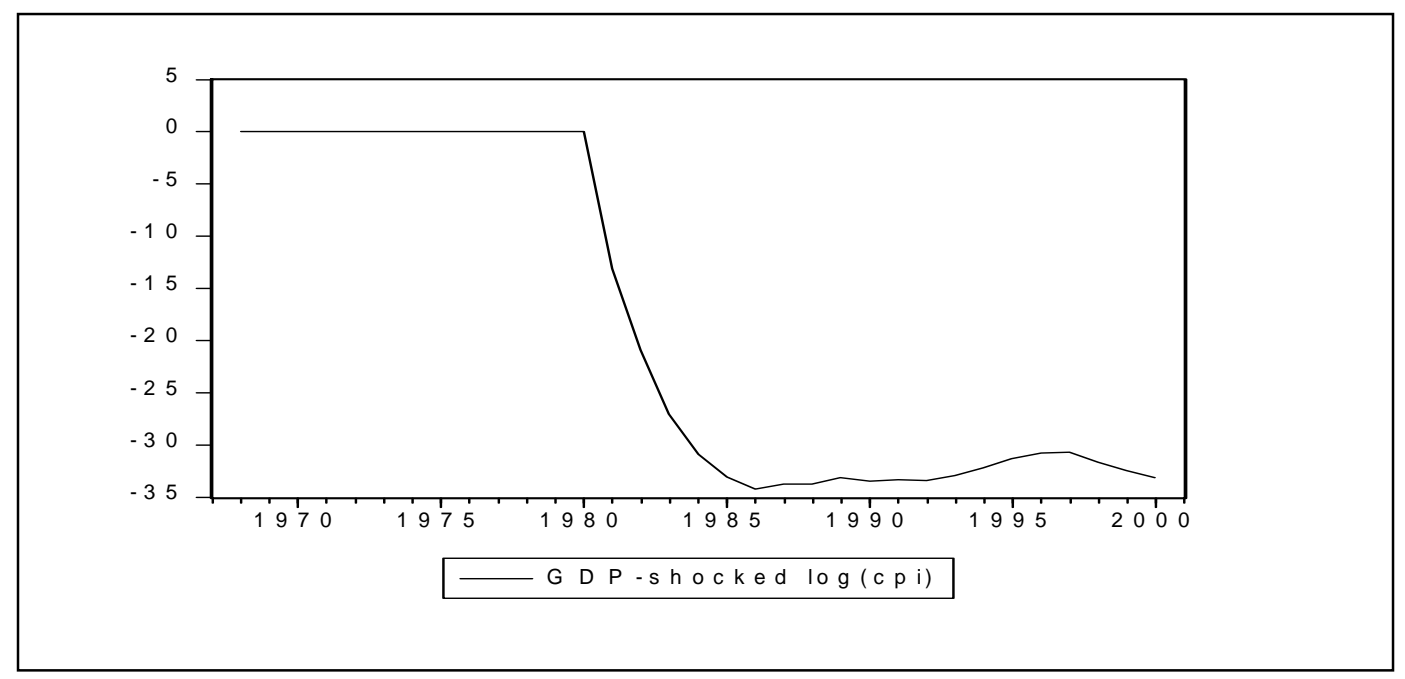

\subsection{Policy implications}

In the past the government has often monetised its budget deficit. This resulted in a high inflation rate for Tanzania. The simulated results showed that increasing the budget deficit profoundly affects the level of prices.

After conducting sensitivity tests, Tanzania's economic growth and budget deficit seem to have a considerable effect on inflation. Increasing the level of economic growth in the country by 10 per cent can permanently lower the level of prices by up to 35 per cent. The growth in GDP, especially if it emanates from the agriculture and food processing industry, could ease the demand pressure for food related products. The consumer price index assigns a weight of 65 per cent for food products in Tanzania. Higher agricultural output will decrease the inflation rate significantly.

These simulations imply that the government could increase the budget deficit marginally. However, in order to keep inflation at low levels, the government should be spending in such a way that it also increases economic growth. This increase in GDP might offset partially or completely, the pressure on the inflation rate from a higher budget deficit.

Although more possibilities emerged in the past few years to finance the fiscal deficit in Tanzania, the fiscal imbalance still has an inflationary impact. Cutting the budget deficit is disinflationary, even more so when the monetised share of 
the budget is falling. Even if the government resorts to non-inflationary financing of the budget deficit, it has to build credibility in government debt management. Economic agents should trust that the government would not be forced to revert to monetisation. Development of an efficient capital market and maintaining the independence of the central bank is a policy alternative for the Tanzania's government.

Although not explicitly simulated in this paper, the elasticity coefficient indicates that the exchange rate has a high and sustained long run effect on inflation. The government should be very careful in its exchange rate management policies.

\section{CONCLUSION}

The relationship between public sector deficits and inflation is one of the important and controversial issues in the academic literature as well as in economic policy field. Using annual data of Tanzania, from 1967-2001, the existence of a stable long run relationship between the budget deficit, exchange rate, GDP and inflation is tested in this study and the result has been affirmative. Using the cointegrating vector found in the study, a significant impact of the budget deficit on inflation in Tanzania cannot be refuted under the assumption of long run monetary neutrality.

Simulations indicate that inflation is very responsive to shocks in the budget deficit as well as GDP. This implication is important for developing countries with inefficient and under developed financial systems. Governments in these countries should take note of the sensitivity of price levels to fiscal policy. The simulations also highlight the supply problem faced by many developing countries. These countries tend to be highly depended on agriculture and producers are at the mercy of weather conditions. Any shock to the agriculture sector has great influence on consumer prices via a decrease in the GDP. As long as developing economies are heavily dependent on the agricultural sector, these shocks are likely to persist. 


\section{APPENDIX A}

Table 2 ADF tests for non-stationarity

\begin{tabular}{|c|c|c|c|c|}
\hline Variable & Lags & Model & $\overline{\tau_{\infty} \tau_{\mu} \tau}$ & $\Phi_{\infty} \Phi_{3}$ \\
\hline \multirow[t]{3}{*}{$\log ($ cpi $)$} & 1 & Trend\&Intercept & -2.50 & 16.98 \\
\hline & 0 & Intercept & -1.45 & 2.10 \\
\hline & 0 & None & -1.49 & \\
\hline \multirow[t]{3}{*}{$\log ($ bdef $)$} & 1 & Trend\&Intercept & -3.96 & 5.29 \\
\hline & 0 & Intercept & -0.76 & 0.58 \\
\hline & 0 & None & -2.08 & \\
\hline \multirow[t]{3}{*}{$\log ($ exch $)$} & 1 & Trend\&Intercept & -2.22 & 13.45 \\
\hline & 0 & Intercept & 1.19 & 4.24 \\
\hline & 0 & None & 1.49 & \\
\hline \multirow[t]{3}{*}{$\log (g d p)$} & 1 & Trend\&Intercept & -2.25 & 5.99 \\
\hline & 0 & Intercept & -1.61 & 2.58 \\
\hline & 1 & None & 2.73 & \\
\hline \multirow[t]{3}{*}{$\Delta \log ($ cpi) } & 0 & Trend\&Intercept & $-6.31 * * *$ & $19.93 * * *$ \\
\hline & 0 & Intercept & $-6.26 * * *$ & $39.13 * * *$ \\
\hline & 0 & None & $-6.34 * * *$ & \\
\hline \multirow[t]{3}{*}{$\Delta \log$ (bdef) } & 2 & Trend\&Intercept & $-6.05 * * *$ & $22.77 * * *$ \\
\hline & 2 & Intercept & $-6.13 * * *$ & $31.26^{* * *}$ \\
\hline & 2 & None & $-6.26 * * *$ & \\
\hline \multirow[t]{3}{*}{$\Delta \log (\mathrm{exch})$} & 1 & Trend\&Intercept & $-5.49 * * *$ & $14.9 * * *$ \\
\hline & 1 & Intercept & $-5.50 * * *$ & $22.50 * * *$ \\
\hline & 1 & None & $-5.60 * * *$ & \\
\hline \multirow[t]{3}{*}{$\Delta \log (\operatorname{gdp})$} & 1 & Trend\&Intercept & -3.14 & 5.12 \\
\hline & 1 & Intercept & $-3.15 * *$ & $9.92 * *$ \\
\hline & 1 & None & -1.46 & \\
\hline
\end{tabular}

$(* *)[* * *]$ Represents rejection of the null hypothesis of the existence of unit roots at $10 \%,(5 \%),[1 \%]$ level of confidence

Table 3 Selection of the order of the VAR: consumer prices

\begin{tabular}{||lcc||}
\hline Order of the VAR & LL & AIC \\
\hline 2 & 99.534 & 67.534 \\
1 & 67.798 & 51.798 \\
\hline
\end{tabular}


Table 4 The Johansen test for the number of cointegrating relationships: consumer prices

\begin{tabular}{||lcccc||}
\hline \multicolumn{4}{||l}{$\begin{array}{l}\text { Cointegration LR test based } \\
\text { stochastic matrix }\end{array}$} \\
\hline Null & Alternative & Statistic & $95 \%$ Critical & $90 \%$ Critical \\
$\mathrm{r}=0$ & $\mathrm{r}=1$ & 79.1997 & 23.92 & 21.58 \\
$\mathrm{r}<=2$ & $\mathrm{r}=2$ & 13.2543 & 17.68 & 15.57 \\
\hline \multicolumn{4}{l}{ Cointegration LR test based on trace of the stochastic matrix } \\
\hline Null & Alternative & Statistic & $95 \%$ Critical & $90 \%$ Critical \\
$\mathrm{r}=0$ & $\mathrm{r}>=1$ & 99.7171 & 39.81 & 36.69 \\
$\mathrm{r}<=2$ & $\mathrm{r}>=2$ & 20.5174 & 24.05 & 21.46 \\
\hline
\end{tabular}

Table 5 Estimate of cointegration equation

\begin{tabular}{|lc||}
\hline \multicolumn{2}{|l||}{ Dependent Variable: $\log ($ cpi $)$} \\
\hline Variable & Coefficient \\
Log(bdef $)$ & 0.445817 \\
Log(exch) & 1.234753 \\
Log(gdp) & -0.487306 \\
\hline Sample period: $1967-2000$ \\
r=1; \\
\hline
\end{tabular}

Table 6 The ECM equations

\begin{tabular}{|c|c|c|c|}
\hline \multicolumn{4}{|c|}{ Dependent Variable: $\Delta \log (\mathrm{CPI})$} \\
\hline Variable & Coeff & Std. Error & istic \\
\hline $\operatorname{resid}_{t-1}$ & -0.054 & 0.031 & -1.74 \\
\hline$\Delta \log (\operatorname{gdp})_{\mathrm{t}}$ & 0.554 & 0.081 & 6.80 \\
\hline$\Delta \log (g d p)_{t-1}$ & 0.397 & 0.079 & 4.97 \\
\hline dum87 & -0.223 & 0.039 & -5.62 \\
\hline Sample period & \multicolumn{3}{|c|}{1969 to 2000} \\
\hline Adjusted R-squared & \multicolumn{3}{|c|}{0.62} \\
\hline s.e & \multicolumn{3}{|l|}{0.055} \\
\hline Purpose of Test & \multicolumn{2}{|l|}{ Test } & Probability $^{*}$ \\
\hline Normality & \multicolumn{2}{|c|}{ Jarque-Bera } & 0.332 \\
\hline Heteroscedasticity & \multicolumn{2}{|c|}{ White Hetr. Test } & 0.279 \\
\hline Serial Correlation & \multicolumn{2}{|c|}{ Breusch-Godfrey LM } & 0.090 \\
\hline Stability & \multicolumn{2}{|c|}{ Ramsey Reset } & 0.205 \\
\hline
\end{tabular}

*Indicates the probability of falsely rejecting the null hypotheses of zero restrictions on the coefficient or diagnostic. 


\section{REFERENCES}

1 ABIZADEH, S. \& YOUSEFI, M. (1998) "Deficits and inflation: An open economy model of the United States", Applied Economics, 30: 107-316.

2 AGHEVLI, B. \& KHAN, M. (1978) "Government deficits and the inflationary process in developing countries", IMF staff papers, 25(3): 383-416.

3 AHKING, F. \& MILLER, S. (1985) "The relationship between government deficits, money growth and inflation", Journal of Macroeconomics, 7(4): 447-67.

4 AKCAY, O. (1996) "Budget deficit, money supply and inflation: evidence from low and high frequency data for Turkey", Bogazici University, Department of Economics, December.

5 BARNHART, S.W. \& DARRAT, A.F (1988) "Budget deficit, money growth and causality: Further OECD evidence", Journal of International Money and Finance, 7(2): 231-42.

6 BUITER, W.H. (1985) "A Guide to public sector debt and deficits". Economic Policy (1): 13-80.

7 CARLSTROM, C.T. \& TIMOTHY S.F. (1999) "Money growth and inflation: Does fiscal policy matter?" Federal Reserve Bank of Cleveland, April 15.

8 CARZONERI, M.; CUMBY, R. \& DIBA, B. (1998) "Is the price level determined by the need of fiscal solvency?" NBER Woking Paper No.6471

9 CATAO, L. \& TERRONES, M. (2001) "Fiscal deficits and inflation: A new look at the emerging market evidence", IMF Working Paper No.74/01.

10 DE HAAN, J. \& ZELHORST, D. (1990) "The impact of government deficits on money growth in developing countries", Journal of International Money and Finance, 9: 445-69.

11 DORNBUSH, R. (1990) "Extreme inflation: dynamics and stabilization" in Brookings Paper on Economic Activity, W.C. Brainard and G.L.Perry (eds.) Brookings Institution.

12 DWYER, G. (1982) "Inflation and government deficits", Economic Inquiry, 20: 315-29.

13 EASTERLY, W. \& SCHMIDT-HEBBEL, K. (1993) "Fiscal deficits and macro economic performance in developing countries", The World Bank Research observer 8(2): 211-37.

14 HAGGER, A.J. (1977) Inflation: Theory and Policy, Macmillan Press Ltd.

15 HAMBURGER, M.J. \& ZWICK, B. (1981) "Deficit, money and inflation", Journal of Monetary Economics, 7. 
16 HONDROYIANNIS, G. \& PAPAPETROU, E. (1997) "Are budget deficits inflationary?" Applied Economics Letters, 4(8): 493-96.

17 KOMULAINEN, T. \& JUKKA, P. (2000) "Fiscal explanations for inflation: any evidence from transition economies" BOFIT Discussion Papers, No.11.

18 MCMILLIN, W. \& V. BEARD, T. (1982) "Deficits, money and inflation: Comment", Journal of Monetary Economics, 10: 273-77.

19 PIONTKIRSKY, R. (2001) "The impact of the budget deficit on inflation in Ukraine", INTAS, May.

20 RUTAYISIRE, LAUREAN W. (1986) "Measurement of government budget deficit and fiscal stance in less developed economy: the case of Tanzania, 1966-84," The University of Dar El Salaam, Eastern Africa Economic Review, 2(2).

21 SACHS, J. \& LARRAIN, F. (1993) Macroeconomics in the Global Economy, Englewood Cliffs, NJ, Prentice Hall, Inc.

22 SARGENT, T. \& WALLACE, N. (1981) "Some unpleasant monetaristic arithmetic", Monetarism in the United Kingdom: 15-41.

23 TANZI, V. (1991) Public Finance in Developing Countries, Edward Elgar Publishing Limited: England.

24 THORBECKE, W (2002), "Budget deficits, inflation risk, and asset prices", Journal of International Money and Finance, 21(4): 539-53.

25 TURNOVSKY, S. \& V MARK, E. (1987) "Alternative modes of deficit financing and endogenous monetary and fiscal policy 1923-1982." NBER Working Paper 2123, January.

26 WALSH E., CARL (1998) Monetary Theory and Policy MIT Press, Cambridge, Massachusetts, London, England. 